Working Paper 9607

\title{
MACRO- AND MICROECONOMIC CONSEQUENCES OF WAGE RIGIDITY
}

by Erica L. Groshen and Mark E. Schweitzer

Erica L. Groshen is a research officer and head of the International Macroeconomics Function at the Federal Reserve Bank of New York, and Mark E. Schweitzer is an economist at the Federal Reserve Bank of Cleveland. The authors would like to thank Daniel J.B. Mitchell for his editorial guidance, and Jennifer Carr and Kristin Roberts for their capable research assistance.

Working papers of the Federal Reserve Bank of Cleveland are preliminary materials circulated to stimulate discussion and critical comment. The views stated herein are those of the authors and not necessarily those of the Federal Reserve Bank of Cleveland, the Federal Reserve Bank of New York, or the Board of Governors of the Federal Reserve System.

Working papers are now available electronically through the Cleveland Fed's home page on the World Wide Web: http://www.clev.frb.org. 


\begin{abstract}
This article reviews a well-established macroeconomic literature -- wage rigidity -- from the perspective of human resource managers and economic researchers. As we demonstrate, human resource policies can subtly alter the rigidity of wages. Fortunately, the potential existence and impact of wage rigidities has long been an active area of economic research whose results can be used to guide human resource managers' policy reviews.
\end{abstract}




\section{A. Introduction}

According to both classical and Keynesian theory, workers who are willing and able -- but jobless -- represent wasted resources that demonstrate an economy's failure to set the proper wage level. Hence, by virtue of causing unemployment, few features of the institutional landscape draw more attention from macroeconomists than wage rigidity. Despite decades of macroeconomic focus, active debate continues on how rigid wages are, why they are rigid, and whether the rigidity has solely negative consequences. Meanwhile, microeconomists and human resource specialists devote remarkably little explicit attention to the phenomenon and its impact on the smooth functioning of labor markets. This is surprising, given the magnitude of economic woes being laid squarely at the feet of wage rigidity in the markets they study.

Indeed, many labor market theories and findings have unexplored implications for wage rigidity. It is the thesis of this article that to fully understand the macroeconomic consequences of wage rigidity (or its opposite, wage flexibility), we need a firm understanding of its micro origins, manifestations, and implications. Similarly, a full understanding of wage-setting from a human resource perspective requires a grasp of the macroeconomic impact of wage rigidity, because these manifestations place pressures on, and represent opportunities for, employers.

This paper explores micro- and macroeconomic theories, implications, and evidence of wage rigidity, in the hope of uniting and informing the hitherto divergent camps. A fuller understanding of the phenomenon should be particularly useful from a policy perspective, since many cross-country and interregional differences in economic performance are thought to reflect differences in their degree of wage flexibility. Indeed, 
a number of policies have been enacted, proposed, or opposed on the grounds of their impact on wage rigidity. Examples include employee stock-option plans, gain-sharing, labor laws, minimum wage hikes, and workplace regulations of various kinds.

We begin by clarifying the concept of wage rigidity under investigation here -- a necessary task in light of its many possible meanings. First, what sort of rigidity do we have in mind: cyclical or secular? In this paper, we focus on cyclical rigidity, that is, the rigidity of wages relative to other economic indicators, particularly those sensitive to the business cycle. We discuss the reasons why nominal or real wages do not fluctuate as much as output, employment, or prices during recessions and expansions. Of necessity, we also touch on the related (but distinct) topic of secular wage rigidity: the failure of real wages to clear the labor market, regardless of the stage of the cycle. ${ }^{1}$ This strand of the literature explores the persistence of involuntary unemployment even during economic expansions.

Second, what type of wages are we dealing with: nominal or real? Since this article is based primarily on U.S. research on domestic human resource practices and issues, our intent is to focus on nominal wage rigidity. Explicit indexation (for example, COLA clauses in union contracts) is relatively uncommon in America. Furthermore, in most cyclical contexts, downward nominal wage rigidity implies real wage rigidity. That is, as Mitchell (1986) points out, nominal cuts always imply real cuts relative to no cut, whereas the converse is not always true. However, since real wage rigidity often provides a starting point for models of nominal rigidity, real wage rigidity models must be introduced.

Third, we focus on wages, not on total compensation. For simplicity, economic models of wage rigidity always consider the narrowest form of remuneration, in which the 
worker is paid solely an hourly wage. However, most workers in the United States receive a wide variety of "fringe" benefits. At the absolute minimum, they receive a set of required benefits. The effects of benefits on wage rigidity depend substantially on employers' ability to alter the value of benefit packages in response to changing economic conditions. While retractions of benefits certainly have occurred in recent economic downturns (offering employers flexibility missed in the wage data), the most complete data available emphasize the continuing secular trend toward higher percentages of total compensation coming from benefits. ${ }^{2}$ Benefits have seldom been included in the analyses primarily because the datasets used to evaluate wage rigidity contain little information on them, not because there is a strong case for benefits altering the rigidity of wages in either direction.

Finally, our standard of rigidity is not absolute constancy, but slower adjustment compared to other economic conditions. Thus, "wage stickiness" is the more accurate term for what we study, but we use the terms rigidity and stickiness interchangeably.

The article proceeds as follows: Section B reviews the various macroeconomic schools of thought regarding the impact of wage stickiness on cyclical unemployment, then summarizes some empirical evidence using aggregate wage data. Section $\mathrm{C}$ introduces the microeconomic and human resource models that explain why rational employers might pay rigid wages to rational workers. We also review the empirical tests of wage stickiness using individual-level data. Section D discusses how employers experience the macroeconomic effects of wage rigidity. The final section summarizes and concludes. 


\section{B. Macroeconomic Roots of the Wage Rigidity Debate}

Because concern over wage rigidity has its roots in studies of unemployment and the business cycle, this section begins by describing the impact of wage rigidity in macroeconomic models. The focus on wage rigidity began with classical macroeconomics, was modified by Keynes, and continues to play an important role in real business cycle models. Thus, we briefly summarize and distinguish among four roles played by wage rigidity in macroeconomic thought. The second half of the section evaluates the aggregate evidence that has been amassed to prove or disprove its existence.

\section{Macroeconomic Models of Unemployment and Wage Rigidity}

\section{a. Classical wage rigidity}

Classical wage rigidity occurs when the real wage level in an economy exceeds the marginal product of labor, causing unemployment. In a steady state, employers hire enough workers so that the boost to output (that is, the marginal product) contributed by the last worker just equals the market wage rate. If the going wage is above the next hire's marginal product, the firm will not hire another, because that worker's wage would exceed the additional production from having him there. This market wage also reflects workers' willingness to work, because if more workers wanted jobs than firms were willing to employ at the market rate, workers would bid down wages until no one was unemployed. 
According to this theory, any involuntary joblessness experienced during regional and national downturns reflects the failure of wages to adjust appropriately following shocks. After a shock that lowers the demand for labor (due to a fall in the price of a product, for example), workers' real wages do not decline immediately. Employers' rigid wages now exceed the marginal product of labor, so, to maintain profitability, they cut staff enough to raise workers' marginal product back up to the wage rate. Jobless workers then find no openings at the going wage rate. Eventually, the unemployed workers bid wages down enough to restore full employment at a new, lower real wage. Until that happens, unemployment persists.

Thus, the focus of classical theory is real wage rigidity. The source of the rigidity depends on the situation in question, so the solution to the unemployment problem varies accordingly. If the price level remains constant, real rigidity is also nominal rigidity.

\section{b. Keynesian unemployment}

By contrast, Keynesian macroeconomics posits and investigates a particular form of rigidity: downward nominal price and/or wage rigidity. That is, Keynesian recessions occur when nominal wage and price stickiness prevents markets from efficiently allocating resources. Because wages cannot adjust rapidly, large economic shocks cause cyclical unemployment. Keynes explained the stickiness by asserting that workers' notions of fairness accept real wage erosion imposed by inflation more easily than they accept nominal cuts. Thus, general wage and price inflation can be a mechanism to reduce cyclical unemployment and to raise economic efficiency. 
An important corollary of this reasoning, developed by Sumner Slichter (see Slichter and Luedicke [1957]) and refined by James Tobin (1972), argues that even without large shocks, moderate rates of inflation can "grease the wheels" of the economy, facilitating downward real price changes in response to small shocks. Hence, inflation can also lower the natural rate of unemployment, raise economic efficiency, and perhaps avoid recessions. For example, Slichter wrote that "the maintenance of a stable price level in the long run would require that the country considerably relax its efforts to keep business recessions as mild as possible," and that we accept "chronic unemployment or drastic intervention by the government in the relations between employers and employees" (Slichter and Luedicke [1957]). This reasoning has also been used to explain the apparent Phillips curve trade-off between inflation and unemployment.

\section{c. Modern developments}

Both of these theories of unemployment suggest that rigid wages may be at the root of the business cycle. However, some recent approaches to the economicfluctuations literature suggest a neutral or even stabilizing influence of rigid wages. In particular, the first real business cycle models removed the emphasis on rigid wages as the main cause of macroeconomic fluctuations. However, this neutral view of rigidity has not persisted; embellishments of real business cycle models and other modern approaches in the macroeconomic literature allow wage (or price) rigidity to play a role in prolonging recessions or in raising the costs of inflation.

In describing real business cycle models of recessions, Lucas and Rapping (1977) use the analogy of islands to represent industries (or perhaps regions) in an economy. After a shock, productive resources must be reallocated among the islands in order to 
maximize efficiency under the new conditions. If prices adjust instantaneously to the new equilibrium levels (because market participants are well informed and rational), it will still take time for resources to "swim" among the islands. During times when many resources are swimming rather than producing (i.e., during periods of rapid structural change), output may fall -- what we call a recession -- until enough resources reach their destinations. In the context of the labor market, the swimming periods can be thought of as job-search or unemployment intervals. Hence, real business cycles occur without wage or price rigidity to generate unemployment.

Other modern economists have now added wage or price stickiness within the context of real business cycle models. Such rigidities slow some agents' speed of adjustment to new price levels, distorting relative price signals until the dust settles. Market participants are unable to discern the true nature of the real shocks because adjustment lags do not allow prices to immediately reflect the full impact of the shocks. Until the lags are fully played out, resources are misallocated and risks are heightened. Such effects could prolong or deepen a shock-induced recession.

Furthermore, inflation -- in an economy with rigidities that induce uneven adjustments -- could exacerbate recessions. For example, Vining and Elwertowski (1976) write, "If general price change instability is highly correlated with and accompanied by price inflation, and if dispersion in individual price changes widens in such periods, ... then a general atmosphere of higher risk and insecurity is the result, a cost of inflation in addition to that associated with the general depreciation of the currency...." Hence, in this scenario inflation acts like sand in the gears of the economy, impairing the smooth transmission of price signals. 
Divergent treatment of wage rigidity thus constitutes a crucial difference between Keynesian and real business cycle models: In Keynesian models, wage rigidity is a key cause of recessions and explains why inflation lightens a downturn. In real business cycle models, this very same wage rigidity is not an essential cause of recessions, but it explains why inflation deepens or prolongs them. Indeed, Ball and Mankiw (1994) argue that the most meaningful way to distinguish between macroeconomists today is on the basis of how important a role they ascribe to sticky prices.

\section{d. Contrarian models}

The last class of models of the relationship between wage rigidity and the business cycle is a contrarian literature which argues that rigid wages may actually smooth economic fluctuations. Hahn and Solow (1986), DeLong and Summers (1984), and Levine (1993) demonstrate that transitions to a new set of equilibrium prices and resource allocations after a shock may well be smoother and entail less output loss if wages change slowly in the correct direction rather than adjusting overnight. The main justification for this line of inquiry is that wage rigidity increased after World War II, while business cycles have lessened in severity. Although this line of reasoning is intriguing, it has not been subjected to much serious scrutiny.

\section{Macroeconomic Evidence}

Given the looseness of the definition of wage rigidity, it is not surprising that the large variety of macroeconometric tests of this measure have failed to yield a consensus in the profession. In addition, the defense of rigidity (or flexibility) of wages has often been in terms of stylized facts rather than econometric tests. We'll start by describing the 
stylized facts and their connection with wage rigidity, then summarize the approaches that have been taken to test wage rigidity. The cited research is certainly not complete; instead, we attempt to cover papers that demonstrate the alternative research directions. A far more inclusive summary is provided by Abraham and Haltiwanger (1995). The often more-direct microeconometric tests of wage rigidity are discussed separately.

\section{a. Stylized facts}

There are two basic characterizations of aggregate wage and employment data that support the existence of wage rigidity. At business cycle frequencies, wage growth varies less than employment, goods prices, and output. Among researchers who have reviewed the stylized facts, Hall (1980) points out a surprising feature of 1970s' business cycles: Even the recessions were characterized by fairly rapid wage growth. Eberts and Groshen (1991) note that this tendency diminished in the 1980s as wage growth slowed. Mitchell (1986) emphasizes that goods prices are more volatile than labor prices, which

points toward a different handling of the price and quantity adjustments in labor and goods markets.

These points are clarified in table 1, which extends the approach of Eberts and Groshen. Changes are summarized by the coefficient of variation, which in turn accounts for the effects of the steady economic growth (for example, due to population expansion) evident in some series but not in others. Once this simple correction is made, it is apparent that wages vary less than either consumer prices, employment, or real output (only the unemployment rate is more stable). Wages and prices both appear to move countercyclically, although this observation is blurred by the need to summarize the quarters for concise presentation. Table 1 can certainly be interpreted as showing that 
much of the output change in U.S. business cycles is absorbed by employment changes rather than by wage changes.

The primary difficulty with these stylized facts is the lack of a metric of comparison. What level indicates flexibility? Are there other factors contributing to the variability of prices or output that need to be considered? How much does the inflexibility affect, directly or indirectly, the health of the economy? Questions such as these push researchers to develop more complicated tools to identify wage rigidity.

The other stylized fact that drives much of the research on wage rigidity is the burgeoning population of unemployed workers, who appear to desire employment at prevailing wage rates. Table 2 shows the substantial rise in industrialized countries' unemployment rates over the last three-and-a-half decades -- a rise that became painfully obvious in the 1980s, particularly in Europe. As Hall (1980) and current BLS figures show, the majority of jobless workers are not relocated smoothly. Although most unemployment spells are short, the unemployment rate is elevated by workers who spend months rather than weeks out of a job. This long-term loss of economic resources does not resemble the macro efficiency condition that requires every worker to be in a job that "makes the best use of the worker's time" (Hall [1980]). While high unemployment rates need not be associated with wage rigidity in the business cycle context (see Lindbeck and Snower [1986]), prevailing macroeconomic rigid-wage models tend to focus on wage rigidity as the sole determinant of labor market failure.

\section{b. Macroeconometric tests}

Macroeconometric tests of wage rigidity pursue several different strategies, depending on the prediction being tested. While many of the early microeconometric 
studies have been quite influential among macroeconomists, we separate them according to whether the tests depend on the variation of aggregates (macroeconometric) or on individual economic agents (microeconometric).

The Cyclical Properties of Real Wages. One of the simpler predictions of rigid wage models is that real wages should be countercyclical; that is, they should be relatively high in recessions and low in expansions. In fact, researchers have found that wages are procyclical (Bils [1985]), countercyclical (Nefci [1978] and Sargent [1978]), or acyclical (Bodkin [1969] and Geary and Kennan [1982]). ${ }^{3}$

One paper that sheds some light on the variety of findings is Sumner and Silver (1989), which shows that the cyclical tendencies of real wages depend strongly on the period of study. Periods characterized by employment changes stemming from aggregate supply shocks (oil crises, etc.) have procyclical real wages, while years dominated by aggregate demand shifts (unanticipated monetary policy movements, etc.) yield countercyclical real wages. Thus, sticky wage models' real wage predictions are borne out in the circumstances the models are intended to explain. Earlier, Hoehn (1988) noted that it was the failure of the standard sticky wage models to account for productivity ("aggregate supply," in the parlance of Sumner and Silver) that excluded the possibility of procyclical real wages.

Clouding this brief bit of clarity is research by Garman and Richards (1992), which separates the roles of price- and wage-level changes from the cyclical properties of real wages. The authors find that real wages are procyclical in a panel of industries. More problematic for rigid wage theories is their conclusion that, at the industry level, nominal wages are more flexible than prices. 
Thus, despite years of research, empirical support for rigid wages based on the cyclicality of real wages is at best uncertain. This support is further complicated by the existence of flexible wage models that also predict countercyclical real wages, notably Lucas and Rapping (1977).

Monetary Neutrality. In a frictionless economy, real wages should be unaffected by money growth -- anticipated or not -- because only real factors can influence economic activity. This suggests another testing strategy: determining to what extent wages are unaffected by monetary policy actions (monetary neutrality). Because wage rigidities in macroeconomic models generally imply monetary nonneutrality, any test of neutrality could be cited as evidence. This section focuses on a recent study (Cogley [1993]) that specifically addresses the effects of monetary policy actions on wages. The emphasis is appropriate because a variety of models predict the nonneutrality of monetary policy without labor market rigidities.

Cogley compares the responses of nominal wages and goods prices to exogenous money shocks using a vector autoregression procedure. Although the technique is complicated, the goal is to identify "exogenous" money shocks, where the monetary aggregates represent both the actions of the supplying monetary authority and the money demand of the public. Cogley's procedures strongly reject monetary neutrality. Further, this rejection results primarily from the difficulty of matching nominal wage dynamics with output. This connection of the wage adjustment process to nonneutrality is supportive of sticky wage models, but could never be definitive in a general equilibrium environment.

International Comparisons. Countries vary substantially in the strength of their business cycles and in their long-run unemployment rates. Does this reflect differences in 
the rigidity of wages? Applying somewhat different approaches, Sachs (1980) and Gordon (1982) both find that U.S. manufacturing wages appear to be more rigid than those in other large developed countries. ${ }^{4}$ Sachs emphasizes the relative insensitivity of U.S. wages to one-year lagged labor market conditions and price expectations. Gordon estimates the fraction of wage bill adjustments associated with wage versus hours-ofemployment adjustments to the changing level of output. Employment was relatively stable in the United Kingdom and Japan for similar changes in GNP. Bell (1986) reaches a very different conclusion about the United States versus West Germany. She disaggregates the data into industry wage changes in each country and then tests the responsiveness of these wages. Her results show that wages in the two countries are equally flexible.

In these international analyses, the issue of "what amount of flexibility is adequate" is critical. Do countries need the same levels of wage flexibility, or are there institutions that alter the trade-offs between rigidity and macroeconomic efficiency? While these studies do not shy away from examining institutions, it is extremely difficult to quantify the effects of varying institutions.

Industry Mean-Wage Dispersion Studies. The final approach, which might be considered a microeconometric technique, starts with the premise that rigid wages should be evident in industry mean wages. Hamermesh (1986) tests whether the observable impact of wage rigidity (that is, the compression of relative wage adjustments) can be detected in industry aggregates that vary in their adjustment policies. He finds a surprising negative effect of both expected and unexpected inflation on the variability of industry relative wages. This is interpreted as favoring the expanded use of wage indexation (where contracts specify adjustments according to a published inflation 
measure) as inflation rises. Card (1990) reaches similar conclusions in a study of inflation's impact on wages set in long-term union contracts. Allen (1987) expands the period of Hamermesh's study and finds that only in the early years does the rigid nominal wage model predict accurately. Even in those years, however, alternative models perform at least as well.

Although these industry studies move closer to the actual transactions where rigidity binds, only microeconomic analyses of adjustments can truly detect wage rigidity. This is because the composition of the workforce varies over the business cycle in ways that cannot be controlled for in aggregate industry wage data.

\section{c. Summary of the macroeconomic evidence}

From a macroeconomic perspective, rigid wages remain a perplexing issue. The evidence goes both ways, and even when it supports wage rigidity, the literature provides alternative models (without wage rigidity) that could yield identical predictions. Primary among these is the model put forward by Lucas and Rapping (1977), which has fully flexible wages and prices. In this model, wage and price variability, along with monetary nonneutrality, result from informational limitations on agents in the economy. The characteristics of this economy are quite similar to sticky wage economies, but the policy recommendations are distinct. Because the macroeconometric tests are based on model predictions rather than on direct observation, pursuing a microeconomic strategy of evaluating wage rigidities might yield better evidence. 


\section{Microeconomic Theories of Wage Rigidity}

\section{The Microeconomic Wage Rigidity Puzzle}

Cyclically rigid wages puzzle economists because they imply that many employers routinely pass up opportunities to improve profits during recessions. Recessions are defined as a general drop in the demand for goods, which firms perceive as a falling price for their products. In a perfectly flexible market, this reduces firms' demand for labor, in turn lowering wages. In response to the wage drop, some workers leave the labor market. So, at the new equilibrium, wages and employment are lower than before, but profits and unemployment return to normal (or zero, in economic terms).

In a rigid wage regime, employers act in concert to preserve their wage levels, responding to the downturn by laying off workers or taking lower profits. Thus, unemployment rises. If, instead, some company reduces its wages below what other firms pay, it could hire workers from the ranks of the unemployed, outcompete the others in the product markets, and earn higher profits. This is the crux of the microeconomic wage rigidity puzzle: How can widespread sticky wage behavior be supported in a profitmaximizing economy?

The solutions to this puzzle argue that profits would be reduced, not raised, by lowering wages. The reason is that wage cuts are very costly because workers perceive them as unfair. But what is unfair about wage cuts, and what kinds of costs can unhappy workers impose? There are two approaches to answering these questions. The first is to derive a stylized economic model that shows the conditions under which wage cuts may not be cost effective. We describe and evaluate four theoretical microeconomic solutions to the puzzle: insurance and implicit contracts, efficiency wages, rent-sharing models, and 
menu costs (i.e., expenses for revising wage schedules). ${ }^{5}$ The first three make more sense as explanations of real wage rigidity, but can be extended to nominal wage rigidity by invoking money illusion, or relative wage considerations. The last story is an explicitly nominal model arising independently from the price dispersion and internal labor market literatures.

The second approach investigates the impact of current workplace institutions (developed mainly after World War II) on measured wage rigidity. These institutions, which address important employment issues (including those captured in the microeconomic theories), have raised the costs of -- or effectively prohibited -- wage cuts (see Mitchell [1986] and Jacoby [1985]). Along this line, we briefly summarize union bargaining models and then develop a more thorough analysis of how current human resource management theories and practices affect wage rigidity.

In no sense are these theories or approaches mutually exclusive, although some are undoubtedly more important than others. Indeed, the microeconomic and organizational behavior approaches are fairly complementary. One way to characterize the difference between the tacks is to note that both assume that wage cuts make workers unhappy and unproductive. While organizational behaviorists study what makes workers happy, microeconomists probe the extent to which worker happiness pays off for a firm. One other hint in negotiating the transition between the two approaches is the reminder that microeconomic models use wages in an abstract sense to represent the entire compensation package, while organizational behaviorists use the term literally. Since the entire package may not be perfectly correlated with measured compensation, entire compensation packages may be more or less rigid than measured wages. 
All of these stories fit better with real rather than nominal wage rigidity, so money illusion on the part of workers must also be invoked to generate cyclical unemployment. Mitchell (1993) points out the separability of nominalism from issues of wage rigidity. If workers are nominalist, they treat the local currency itself (rather than what it can

purchase) as a standard of value. A simple example would be the persistence of a million dollars as a standard of great wealth. More to the point, levels of nominal pay may function as workers' standards of value in judging the appropriateness of their compensation. Although standards often originate from historical accidents, they can be difficult to abandon because a widespread commitment to a new standard is needed to overcome the momentum of the existing one.

Mitchell's helpful separation of these two issues directs our attention to the remaining problematic question of why economic agents would continue to neglect the harms of rigid wages that we have outlined above. Thus, we now proceed to models that examine potential gains from wage rigidity.

\section{Four Microeconomic Theories of Wage Stickiness}

Insurance models suggest that employers do not lower wages during recessions because their workers have been accepting slightly lower wages all along under the condition that their paychecks won't vary over the cycle. That is, firms provide wage insurance for their employees. Alternatively, efficiency-wage and rent-sharing models predict that some wages permanently exceed the full-employment wage. These theories can be extended to cyclical wage rigidity by assuming that some of these premia are paid out in the form of insurance over the cycle. 


\section{a. Insurance and implicit contract models}

Insurance/contracting models describe workers and employers as operating under

long-term contracts that specify (in advance) workers' wage rates over the life of the contract (Azariadis and Stiglitz [1983]). Such contracts may be explicit, such as in collective bargaining agreements, or implicit, such as employers' infrequent redesign of occupational salary scales. These contracts are motivated by workers' desire for wage “insurance." Because employers are assumed to be less risk averse (since firm owners can diversify their portfolios better through the capital market, or because they self-select into business ownership) or better informed about current economic conditions, it becomes mutually advantageous to enter into a long-term arrangement. In these contracts, firms assume at least the main portion of the underlying risk associated with shocks by guaranteeing their workers a fixed wage rate. Employers do not "cheat" on implicit contracts because they would be unable to hire new workers or recontract in the future.

Thus, when a shock strikes, only a fraction of the economy's wages can adjust quickly: those of workers whose contracts are currently under negotiation. Employers facing lower prices for their goods then lay off workers. Gray (1976) and Fischer (1977a, 1977b) use this explanation of wage stickiness in their Keynesian models of economic recessions. These models demonstrate a role for the "grease" effects of monetary policy.

Recent versions of contracting models address two main criticisms: that not enough of the U.S. workforce is employed under long-term contracts, and that their assumptions imply irrationality on the part of workers (Barro [1977]). For example, to the extent that workers quit declining industries to pursue opportunities in growing 
companies (as in Holmstrom [1983]) the wage stickiness can be muted, but the results continue to hold. In another approach, Azariadis (1983) describes the value of wage contracts to workers if they are less informed than their employers. Gray, Kandil, and Spencer (1992) extend the model to the case of economies with contracted and noncontracted sectors and find support for the model with historical data.

\section{b. Efficiency wages}

Efficiency-wage arguments posit a causal relationship between wage levels and a worker's on-the-job productivity (see Katz [1987]). A high wage induces workers to be more productive than they would be in a low-wage environment. Efficiency-wage employers pay workers a premium above the market-clearing wage because the resulting increment in productivity yields the highest profits. The increased productivity has been modeled as coming from three sources: reduced monitoring (or shirking) costs, decreased turnover, and sociological considerations.

In the monitoring/shirking version, workers' effort is costly to monitor (Bulow and Summers [1986], Shapiro and Stiglitz [1984]). Higher wages reduce a worker's incentive to shirk, because shirking increases the probability of losing a high-wage job -- leading to lower supervisory costs for high-wage employers. The turnover version emphasizes employer costs of hiring and training (Salop [1979]). Wages above equilibrium reduce turnover because workers have fewer superior alternatives and/or because the general level of unemployment rises. Two related search/recruiting versions of the model show that firms with high costs of unfilled vacancies may offer above-average wages to fill those spots more quickly (Lang [1987], Montgomery [1987]). A third variant of the 
argument shows that group work norms (which depend on sociological morale, loyalty, or teamwork) are raised by wages above the minimum required (Akerlof [1982]).

\section{c. Rent-sharing or insider/outsider models}

According to an alternative category of explanations -- rent-sharing or

insider/outsider models -- workers may be able to capture their employers' rents or quasirents in the form of above-market-clearing wages. Perhaps some employers earn and "share" unusually high profits (i.e., "rents") in the form of higher wages. Since this sharing shrinks the profits that would otherwise accrue to the owners, it cannot be presumed to be strictly voluntary. Rather, it may reflect the fact that training or hiring costs for firms are high, that it is hard to ensure that employees do not sabotage or damage the firm's capital, or that owners are so removed from day-to-day management that they do not detect the largess.

When bargaining over rents between workers and their employers takes place in the context of competitive labor and capital markets, bargained wages cannot differ from the market-clearing wage. Otherwise, the firm would close or the workers would leave. However, if employees can claim some of the rents generated by an enterprise, they will bargain (implicitly or explicitly) with their employers. Wage settlements will then reflect both the size of rents and the balance of bargaining power between the parties.

The models differ in the identity of the bargaining agents and in the enforcement mechanisms for the bargaining. Most clear is the case of unionism, where the agents are the union and management. ${ }^{6}$ Solow (1985) and Lindbeck and Snower (1987) outline versions based on firm-specific human capital. This, however, raises the question of why these firms persist in providing firm-specific training. Alternatively, in the managerial- 
capitalism or agency-cost version, managers mediate between labor and the owners of the firm. If managers' pay is poorly correlated with rents to the owners, or if managers care about worker satisfaction (whether through altruism or workers' ability to impose on-thejob problems), then implicit bargaining may occur. Management may be cast in various roles from agent for the workers, to mediator between the two sets of interests, to agent for the owners. The latter role generates a model all but institutionally indistinguishable from a union bargaining model.

\section{d. Menu costs}

An important source of price/wage rigidities posited in the price dispersion literature is menu costs (i.e., expenses for revising price lists), which imply that real or inflationary price changes are unlikely to be transmitted uniformly and instantaneously. Strictly speaking, menu-cost models of the labor market belong to the class of efficiencywage models, because they imply that setting (or maintaining) an above-market wage for equivalent workers can be a profit-maximizing strategy. However, the mechanisms and the literatures are distinct enough that we consider them separately.

Menu-cost models (see Sheshinski and Weiss [1977], Mankiw [1985], and Akerlof and Yellen [1985]) show that monopolistically competitive sellers who face costly price adjustments modify their nominal prices infrequently. As inflation or real price pressures rise, the band within which each seller allows its real price to drift between adjustments widens, increasing the marketplace dispersion of prices and price changes.

If we think of employers as monopsonistic competitors, this model explains why firms adjust most workers' wages infrequently (generally annually) and suggests that they 
set their wages in anticipation of losing ground to their competitors over the course of the year. It also suggests that -- up to some limit that depends on the magnitude of menu costs involved -- small wage cuts may simply not be worth implementing. Thus, wages will be rigid between periodic adjustments, and small changes will be infrequent even at the normal time of adjustment. This model is quite similar to the market insulation version of the efficiency wage story.

The internal labor market literature adds two more possible stories: market insulation and corporate consistency. These two variants, as described by Doeringer and Piore (1971), focus on firm-specific human capital and on the out-of-pocket and morale costs of designing a compensation package for a group of employees. Keeping wages constantly set at market-clearing levels requires periodic readjustments in response to shocks in the external labor market. Yet, redesign of wage schedules may be expensive for employers. In addition, changes in relative wage relationships may be perceived as inequitable or as a breach of implicit contract and thus will reduce effort or raise turnover. An alternative to frequent, disruptive adjustments to market fluctuations is to pay above-market wages. If, on average, workers receive a premium, then small wage shocks relative to the premium will not force a firm to readjust its compensation package. Employers save out-of-pocket and productivity costs of the adjustment, at the expense of a higher wage bill.

Corporate consistency, the second internal labor market version, is based on firms' tendency to promote from within rather than hire from outside, presumably to retain workers with firm-specific human capital. Such a policy requires that internal wages for each occupation in each plant be no less than 1) local wages for the occupation (lest workers leave the firm) and 2) firmwide wages for that occupation (lest workers refuse 
transfers to the plant). ${ }^{7}$ This implies identical wage structures for plants within the firm regardless of local economic conditions, with each occupation earning the maximum local rate over all plant locations.

\section{Monopoly Power of Unions}

In many ways, unions represent a convenient explanation for wage rigidity. Indeed, unions are prominently featured in the macroeconomic empirical work (see Sachs [1980] and Gordon [1982]). With the correct preferences, a union could negotiate contracts that preserve the wages of the majority at the cost of marginal workers. For example, a union that follows a median voter rule (in which at least a plurality must benefit from its decisions) can easily be shown to act to preserve the wages of established workers who are protected by seniority rules (Medoff [1979]). In addition, other bargaining models can yield more interesting results, such as wages that adjust in response to a limited number of credible signals. ${ }^{8}$

Since unions are not the focus of this article, we refer the interested reader to the larger unionization literature, while noting that unions cover a diminishing fraction of the U.S. workforce, and that the degree to which the union wage negotiation process alters wages for nonunion workers is unclear. Furthermore, incentives that are effective with nonunion employees may be applicable to unionized employees as well.

\section{Human Resource Management Theory and Wage Rigidity}

The final category of potential wage rigidities stems from the "fair-pay" models advanced by organizational behaviorists. Unlike the previous theories, which derive economic conditions that could yield wage rigidities, these theories are not intended to 
explain wage stickiness. ${ }^{9}$ Rather, wage rigidity is a by-product of employer wage policies designed to address fair-pay issues. Theories of wage fairness can be split into three categories, as in Dornstein (1991): relative deprivation theory, equity theory, and status value theory. While each of these categories has its own advantages, modern enhancements, and critiques, this section emphasizes equity theory because it is most directly connected to typical institutional wage policies.

\section{a. Equity theory}

Equity theory, as developed by Adams (1963a, 1963b), can be summarized by using a simple ratio of individual compensation to individual inputs. The focal person compares his own ratio to that of some relevant group to judge the fairness of his compensation. One clear way in which equity theory differs from the approach taken by empirical economists is that the comparison includes differences between inputs rather than simply between wages and benefits. Inputs can include effort level, required skills, and allowance for work conditions. Three conclusions are possible, depending on the relative size of these ratios: fairly rewarded (equity), under-rewarded, and over-rewarded.

$$
\text { if }\left(\frac{O_{f}}{I_{f}}\right)=\left(\frac{O_{o}}{I_{o}}\right) \text { then }\left\{\begin{array}{c}
\text { Under-rewarded } \\
\text { Equity } \\
\text { Over-rewarded }
\end{array}\right.
$$

While the approach is simple, each employee has many possible comparisons, some of which could yield conflicting results. To address this problem of multidimensionality, researchers have proposed a variety of categories of equity comparisons. Particularly relevant for our analysis are the three categories suggested by Wallace and Fay (1988): external, internal, and individual. External comparisons focus on 
positions outside the worker's firm, which are easily interpretable as the worker's labor market options. Internal equity contrasts one's job to other jobs within the firm. Comparable-worth cases represent a prominent example of internal equity comparisons. Finally, workers may compare their situation with that of other workers in their job (occupation and firm). For example, senior workers may compare their treatment with their evaluation of a new hire.

While equity theory usually focuses on comparisons with other workers, individual equity at its simplest compares a worker's current situation with past experiences. Prichard (1969) discusses comparisons on the basis of internal standards derived from the worker's "past experience in exchange relationships and the knowledge of the 'market value' of various outputs." Most relevant to issues of wage rigidity, this perspective implies that employees compare their current wages and effort levels with those of their recent past.

How do workers react to inequities? Although they may search for new opportunities, some may alter their effort level (in jobs where monitoring is imperfect). Anticipation of this reaction may alter the firm's decision, as we saw with efficiency wages. Let's consider a hypothetical case of how equity might generate wage rigidities. Suppose workers in a particular occupation experience a fall in the demand for their services in the local labor market. External equity (and standard microeconomic theory) suggests that the firm should lower these workers' wages to correspond with the new market conditions. Workers may, however, compare their position with other occupations in the firm, other workers in their occupation who may be sheltered from the adjustment, or their own wages in a previous period. Although equity theory does not tell us how the 
conflicts between the comparisons will be resolved, it argues that firms may limit salary reductions in order to avoid lower effort by the affected workers.

\section{b. Implementation of equity theory by firms}

Workers' comparisons lead firms to establish compensation policies oriented toward comparisons between the firms' employees and their relevant internal and external groups. The importance of equity theory for understanding wage rigidity lies in the assertion that the mechanisms used by firms to address wage equity result in rigid wages. Concern over internal equity is addressed by evaluating jobs and defining pay grades. The need for external equity motivates firms to conduct or subscribe to salary surveys or to consult in some other way with outside sources on local wage rates. While less formal, the vast majority of firms also implement performance-based "merit pay," which rewards higher individual performance (individual equity). At each level of comparison, firms' information is limited; thus, they adapt practices intended to ensure equity or the perception of equity. ${ }^{10}$

A common implementation of internal equity is a job evaluation system tied to an array of pay grades. In order to associate each job with a level of expected worker input, a scale of inputs is developed that spans occupations. While the components of job evaluation vary substantially from system to system, most are similar to the “compensable factors" defined by the National War Labor Board during World War II: 1) responsibility, 2) skill required by the job, 3) effort required, and 4) work conditions. In fact, these compensable factors were codified by the Equal Pay Act of 1963, which sought to ensure equal pay for equal work for women. ${ }^{11}$ Based on these or similar factors, the job evaluator assigns points to each job for each factor. These points can be 
used to rank and group jobs into job families and pay grades. Job families are differing levels of the same occupation (for example, Secretaries I to V), while pay grades group people of varying occupations for purposes of pay comparability.

External equity is implemented by analyzing pay in the relevant market, defined by the local area, the product market, or other relevant competitors. Wages can be surveyed within the market of interest, or data can be collected from public sources. Regardless of which technique is used, issues arise regarding how relative wage information is integrated with the firm's wage structure. How well do the numbers collected reflect the market opportunities of the employer's workforce? Does the firm want to match the market or to operate with labor costs that are some fraction above or below the market? Choices such as these can easily be justified in terms of either the effort or skill levels sought.

Firms generally address both internal and external equity concerns through use of an explicit pay structure. The pay structure combines job points and pay grades with market data to define a trend line (see figure 1). Around the trend line are the pay ranges associated with each pay grade and, therefore, with each job title. Many compensation texts recommend a simple linear regression of market wage rates on job points to define the trend line. Other options include freehand drawing of the trend line, and quadratic and kinked regression specifications (Hills [1987], chapter 10). The trend line, combined with the range of pay allowed for performance or seniority differences, determines the upper and lower bounds of wages for each pay grade.

Pay grades can render wages rigid because the ranges and midpoints that they impose limit pay variation. Once job titles have been associated with pay grades (which are infrequently adjusted), workers whose external wages are either high or low relative to 
the midpoint have their possible wage adjustments truncated by the bounds. Furthermore, the application of the pay structure is often evaluated in terms of "compa" ratios (the ratio of the market mean to the wage structure midpoint), which can lead to more widespread limitations if the functional form chosen for the pay structure does not match the market closely. Equity theory and firm pay structures work well as an explanation for potential wage rigidities because of their broad application among U.S. employers.

\section{Microeconomic Evidence}

\section{a. Individual data}

Studies of wage rigidity in microeconomic data yield mixed results. In an interesting combination of papers, McLaughlin (1991), Lebow, Stockton, and Wascher (1994), and Kahn (1994) all examine the Michigan Panel Study of Income Dynamics (PSID) for evidence of downward nominal wage rigidity. Focusing on job stayers, all three studies test whether there are fewer wage cuts and more heaping at zero than would be expected with flexible wages. Researchers using the PSID must select the empirical wage concept to analyze, as the PSID allows workers to report their earnings in the most convenient manner for the subject. This results in wage reports that include annual earnings for some workers along with hourly wages for others, complicating the interpretation of even simple histograms of wage adjustments. The study methods, sample exclusions, and treatment of workers' hours vary. McLaughlin and Lebow et al. find little or no evidence of downward wage rigidity, while Kahn finds strong statistical support for rigidities, but more so for hourly workers than for salaried employees. At this time, the divergent results have not yet been reconciled. 
Holzer and Montgomery (1990) study the impact of changes in firms' sales (as a proxy for demand shocks) on employment and entry-level workers' wages. Consistent with predictions of the sticky nominal wage model, they find that increases in sales are associated with wage hikes to a far greater degree than sales decreases show up in wage cuts. They also find that employment changes are more closely related to sales fluctuations than are wage changes. The latter effect, while consistent with the sticky wage hypothesis, could also arise from the idiosyncrasy of the demand shock to different employers. When a demand shock hits a single employer in a large market, the market wage should not be affected much, so most of the firm's adjustment should be via employment.

One problem with all of these studies is that the existence of nominal wage cuts per se does not demonstrate that wages are flexible. Economically meaningful wage rigidity occurs when wages do not adjust adequately to avoid unemployment. On the one hand, employers have many other ways to adjust their wage bills besides reducing nominal wages (hours, responses to attrition, promotions, reassignments), so average earnings may be quite flexible even without nominal wage cuts. On the other hand, even all of the negative wage changes observed in these micro-level studies may not have been enough to avoid disequilibrium. Hence, convincing proof or disproof of wage flexibility hinges more on tests of the implications of rigidity than on exercises to identify nominal wage cuts.

\section{b. Human resource managers' studies}

Since theories of wage rigidity are inherently difficult to distinguish or verify, another group of recent empirical efforts takes the unusual approach of surveying 
employers directly. Five examples are Blinder and Choi (1990), Kaufman (1984), Bewley and Brainard (1993), Blanchflower and Oswald (1987), and Levine (1993), which uniformly suggest that notions of fairness are important governing principles in employers' wage-setting practices. Although these studies draw less uniform conclusions on the underlying reason for this rigidity, they all report that employers refrain from nominal wage cuts except under extreme duress, implying that wage stickiness indeed slows the adjustment to economic shocks. Clearly, however, wages are not completely rigid downward.

One problem with these studies is that there is no way of knowing if managers achieve flexibility in their wage bill in ways other than simply adjusting wage rates. For example, these studies do not examine links between hiring/firing policies and wage administration policy.

Other results are less uniform and reflect differences in approach. Levine (1993) finds wages to be symmetrically rigid. Bewley and Brainard (1993) find some support for efficiency wage hypotheses. Neither Levine (1994), Bewley and Brainard (1994), nor Blinder and Choi (1990) find evidence to support rent-sharing stories. The menu- cost and insurance stories are not explicitly covered in any of these studies.

\section{c. Money illusion studies}

Strictly speaking, money illusion and wage stickiness are distinct phenomena. However, as discussed above, three of the four microeconomic theories rely on money illusion (or its observational equivalent, caring most about relative wages) to transform their predictions of real wage stickiness into nominal wage stickiness. In this context, money illusion means that workers consider employers to have complied with the terms of 
their bargain if nominal wages maintain the agreed-upon path, regardless of what happens to prices. ${ }^{12}$ From this perspective, what the employer offers in the insurance contract, efficiency wage, or profit share is not a real wage guarantee, but a relative one -- a certain standing vis-à-vis some reference group. The reasoning is that individual wage cuts are far more likely to reduce a worker's relative standard of living than are the uniformly distributed losses of real earnings resulting from a general price rise.

Thus, the plausibility of money illusion by actors in the labor market is a necessary (though not sufficient) condition for the insurance, efficiency wage, and rentsharing stories to explain wage rigidity. Finding evidence that workers do not act as if they had money illusion would contradict these models of nominal wage stickiness. Interestingly, most direct tests suggest that money illusion is prevalent in the labor market and figures strongly in concepts of fairness. ${ }^{13}$ These findings supply important supporting evidence for nominal wage stickiness.

\section{d. Firm-level data}

One final micro-level approach is to examine firm-level data for evidence. In the only study we know of using firm data, Groshen and Schweitzer (1995) test two important implications of wage rigidity for the labor market: the Keynesian prediction that higher inflation facilitates the adjustment of interoccupational (relative) wages to shocks, and the new monetarist prediction that higher inflation generates more noise in employers' mean wage changes (presumably because of greater disagreement about the path of prices, or because of divergent adjustment paths). Using a 37-year panel of wage changes for occupations within firms, support is found for both models, because wage changes are shown to have large, independent employer and occupation components, and the 
dispersion of both components increases with inflation. Thus, the data suggest that wage rigidity plays an important micro- and macroeconomic role.

\section{e. Summary: Linking up the contradictory evidence}

With only two exceptions (the McLaughlin and Lebow et al. papers), all of the micro-level studies cited here find some evidence to support wage stickiness and the related phenomenon of money illusion. While none of the studies may be fully convincing in its own right, the diversity of approaches, combined with the consistency of results, suggests that wages are indeed sticky. Judged primarily on the basis of the survey evidence, rent-sharing models appear to fare worse than the efficiency wage explanation.

Yet, it is difficult to evaluate the severity of this observed stickiness, because we have no way to gauge how much wages should have adjusted to clear the market. Moreover, employers' ability to adjust their costs by means other than changing wage rates clouds the connection between individuals' rigid wages and aggregate unemployment. These conclusions point to the necessity of developing and testing firmlevel predictions of the impact of wage rigidity.

\section{Microeconomic Implications of Wage Rigidity}

\section{General Framework}

In this section, we delve further into the microeconomic ramifications of wage rigidity for firms, focusing on problems that wage stickiness causes for managing human resources. First, we introduce the general framework used to examine the impact of wage stickiness on unemployment, sectoral allocation, and wage compression. 
We begin by noting that, regardless of the reasons for wage rigidity, wage adjustments in a sticky world can be described by the following decision problem:

$$
\begin{aligned}
\min _{\mathrm{w}} \sum \alpha_{\mathrm{i}}\left(\mathrm{w}_{\mathrm{i}}-\mathrm{w}_{\mathrm{i}}^{*}\right) & \\
\text { s.t. (I) } \Sigma_{\mathrm{i}} \mathrm{w}_{\mathrm{i}} \leq \mathrm{B} & \text { \{budget\} } \\
\text { (II) } \mathrm{w}_{\mathrm{i}} \geq \mathrm{c} \forall \mathrm{i} & \text { \{simple downward wage rigidity\}. }
\end{aligned}
$$

The firm's goal is to match the market's wage movements. This is modeled as minimizing the weighted sum of differences between wage-change offers $\left(\mathrm{w}_{\mathrm{i}}\right)$ and the desired wage changes $\left(\mathrm{w}_{\mathrm{i}}^{*}\right)$ for each worker $\mathrm{i}$, subject to an overall wage-change budget (B) and a rigid wage constraint (c). The simple downward wage rigidity constraint (II) could allow no nominal wage reductions $(\mathrm{c}=0)$, no real reductions $(\mathrm{c}=$ inflation rate), or perfect flexibility $(\mathrm{c}=$ negative infinity $)$.

The two constraints may conflict with each other. That is, in order to stay within its budget, a firm may want to match market reductions in some wages by more than the rigid wage constraint allows. However, if $\mathrm{c}$ is a nominal figure (such as 0 ), while wages and budgets rise together with inflation, high inflation renders fewer individual wage changes subject to the rigid wage constraint. Thus, inflation relaxes wage rigidity constraints.

Interestingly, downwardly rigid rules may also constrain wage raises during periods of low inflation. When the compensation budget (constraint I) binds, it limits wage adjustments to those that can be balanced elsewhere. Thus, each occurrence of a wage constrained to exceed $\mathrm{w}_{\mathrm{i}}{ }^{*}$ constrains other wage changes. While the traditional story of rigid wages stresses the unemployment consequences, a firm might choose to limit higher-than-average desired increases rather than to lay off workers. The simple 
conclusion is that binding downward wage rigidities reduce the variance of wage adjustments, first by eliminating many wage cuts, and second by restraining increases in order to balance the compensation budget.

Of course, empirical evidence (such as that found in studies of the human resource managers surveys summarized above) suggests that simple wage constraints like II are probably too extreme. Equity theory suggests a more general constraint; for example,

(III) $\left\{-\gamma \overline{W_{i}}-\left(W_{i}^{0}-\overline{W_{i}}\right)\right\} \leq \mathrm{w}_{\mathrm{i}} \leq\left\{\gamma \overline{W_{i}}+\left(W_{i}^{0}-\overline{W_{i}}\right)\right\} \forall \mathrm{i} \quad$ \{wage structure rigidity $\}$.

This more general wage constraint (III) can substitute for simple downward wage rigidity and represents the wage structure for a given worker. The W's represent relevant wage levels rather than wage changes, because the range available to the worker depends on the relative values of his current wage $\left(W_{i}^{0}\right)$ and on the defined features of his wage grade (that is, the central wage, $\overline{W_{i}}$, and the fraction by which the bounds extend beyond the central wage, $\gamma$ ). Obviously, this wage constraint limits both directions of wage movements, but downward wage rigidity is implied as a special case.

\section{Unemployment}

In the basic macroeconomic framework, rigid wages cause unemployment because equivalent workers are willing to work at wages lower than those offered by the firm. The application of this logic is not nearly so straightforward in the framework outlined above. What categories of worker are affected in what situations? 
Consider a firm that employs two occupations ( $\mathbf{a}$ and $\mathbf{b}$ ), each originally earning its market mean wage. Suppose that the market wage adjustment is negative for the a group $\left(\mathrm{w}_{\mathrm{a}}{ }^{*}\right)$ and positive for the $\mathbf{b}$ group $\left(\mathrm{w}_{\mathrm{b}}{ }^{*}\right)$, as shown in figure 2. A downward wage rigidity potentially binds for occupation $\mathbf{a}: \mathrm{w}_{\mathrm{a}}{ }^{*}<\mathrm{c} \Rightarrow \mathrm{w}_{\mathrm{a}}=\mathrm{c}$. That might very well result in the unemployment of available a workers, because the firm (and others so constrained) will be unwilling to hire more a workers as long as the wage has not fully adjusted. On the other hand, the firm has an incentive to hire any available $\mathbf{b}$ workers (if possible) after

the firm's budget-limited wage adjustment ( $\left.w_{b}=\frac{W-n_{a} w_{a}}{n_{b}}\right)$. Thus, by this logic, wage rigidity results in unemployment for the downwardly constrained occupation, but not for the upwardly constrained occupation.

\section{Mobility and Sectoral Reallocation}

In the situation above, a workers in the firm earn more than their market wage $\left(\mathrm{w}_{\mathrm{a}}{ }^{*}\right)$, so they do not receive the market signal that they should evaluate other options. For example, experienced workers may continue to work in a declining industry beyond the time when it would be socially more efficient for them to pursue new skills. Although this result may appear to conflict with the unemployment effects noted previously, these situations can occur simultaneously with heterogeneous workers. Lower-skilled a workers may continue to seek employment in a jobs after the wage reduction, while the employed worker would pursue other work if his wages were adjusted by $\mathrm{w}_{\mathrm{a}}{ }^{*}$.

This is not the full story for most constrained wage adjustments. Remember that both worker groups (a and $\mathbf{b}$ ) have their wages altered if the budget constraint binds. Thus, workers in group $\mathbf{b}$ will be exposed to a growing incentive $\left(\mathrm{w}_{\mathrm{b}} *-\mathrm{w}_{\mathrm{b}}\right)$ to investigate 
their options outside the firm. The firm's ability to keep these employees will depend on the workers' costs of mobility. This is the issue that human resource managers face most directly in the form of complaints, such as "we're not keeping our best $\mathbf{b}$ workers." The issue is not likely to be as straightforward as the two-group example, however. The actual groups whose wages are held down to equalize the artificially propped up wage would depend on the $\alpha$ weights, which represent the firm's assessment of the categories of workers who must be kept closest to their market wage.

\section{Wage Compression}

Wage compression is a problem that firms normally describe in terms of their career ladders. If internal wage adjustments for an occupation are constrained to show only steady growth, while the market for new hires is booming, the range between the most junior and senior workers may shrink (Bergmann and Hills [1987]). Business schools in the 1980s represent an excellent example. Between 1977 and 1986, "the pay ratio between assistant and associate professors narrowed by over 60 percent" (Gomez-Mejia and Balkin [1987]). Although this situation is not the same as the rigidity-induced unemployment described above, the firm's problem is similar. To see this, consider the more general form (III) of wage rigidity constraints, where workers' wages are limited by both the upper and lower bounds of their pay grade.

Figure 3 shows this situation for another hypothetical workforce with two levels ( $\mathbf{s}$ and $\mathbf{j}$ workers, for senior and junior employees). Here, $\mathbf{s}$ workers' wages are limited to the range between $-d_{1}$ and $+d_{2}$, which, along with the budget, makes the desired equilibrium (indicated by *) impossible. The desired equilibrium reflects a sharp rise in the observed market wages of $\mathbf{j}$ workers, and the extension of that rise to the market for 
experienced $\mathbf{s}$ workers. The need to meet the market for new hires ( $\mathbf{j}$ workers) leads to a range of possible solutions (although we might expect the firm to choose the lowest-cost point), where changes for $\mathbf{s}$ workers are $+d_{2}$, and wages for $\mathbf{j}$ workers are at least $\mathrm{w}_{\mathrm{j}}{ }^{*}$. This example, while specific to the diagram as shown, points out the broad impact of the more general wage rigidity implied by wage structures. Once again, constrained workers now have incentives to switch jobs.

\section{Avoidance Costs and Summary of Microeconomic Implications}

At this point, some readers might wonder why firms would continue so blindly in this framework, when the implications are potentially huge. Obviously, there are limits to what firms will accept. On the other hand, it is not generally costless, particularly from the human resource manager's standpoint, to alter or avoid the firm's stated compensation policies. Any of the theories that propose reasons for pay rigidities, including equity theory, suggest that ignoring the factors which support these rigidities will have costs. From the economist's perspective, these costs may be unmeasurable, but they could be quite real within the firm.

In this section, we attempt to move beyond the simple macroeconomic model of labor markets by considering firms with heterogeneous workers. This extension of the model immediately shifts attention from the implied unemployment rate and wage growth to who is affected and in what way. While variations in the underlying microeconomic reasons for wage rigidity might alter the cost/benefit mix, the lesson remains that the costs are potentially widespread and can affect workers who would appear to be isolated. 


\section{E. Conclusion}

Historically, wage rigidity has been a macroeconomic topic because it may create or aggravate involuntary unemployment during recessions. In this article, we have explored the macroeconomic theories and the inconclusive aggregate-level evidence on sticky wages. We then turned to the microeconomic and organizational behavior theories underlying sticky wages. With two exceptions, the micro-level empirical studies are more uniformly suggestive of wage rigidity, but have no metric of what constitutes "enough" flexibility.

Our theme throughout (explored in more detail in the preceding section) has been that the microeconomic consequences of wage rigidity impose substantial costs on employers, which can be gauged by the size of the macroeconomic consequences. This realization has three implications. First, it suggests that the perceived benefits of rigidity (streamlining and reducing uncertainty in what might otherwise be an unruly wage-setting process) must also be substantial. Second, it suggests the value of considering the macroeconomic consequences of micro-level compensation policies, because the results indicate opportunities for exploiting other firms' behavior.

Finally, this approach implies that employers may make substantial gains if they can identify ways to achieve the benefits of wage rigidity without suffering the costs. Until the macroeconomic consequences disappear, there will always be an incentive to innovate to alleviate the inflexibility of wages. This search may be one way to understand many innovations taking place today (with varying degrees of success) in U.S. human resource practices. Examples include two-tier wage structures, contracting out for 
various functions, declining establishment size, "broad-banding" salary ranges, pay for performance, and gain-sharing.

${ }^{1}$ For a review of this genre of theories and evidence, see Groshen (1991).

${ }^{2}$ The Employment Cost Indices collected by the Bureau of Labor Statistics (BLS) after 1987 allow accurate separations of benefit costs as a fraction of total employment costs. From 1987 to 1994 , the ratio of benefits to total compensation rose steadily from 26.8 percent to 28.9 percent.

${ }^{3}$ This literature list is intended to be illustrative rather than complete. It lacks, among others, the early papers on the topic, such as Dunlop (1938) and Keynes (1939). Also, Bils (1985) is a microeconometric study, but it clearly fits with this macroeconometric approach.

${ }^{4}$ Sachs compares the seven largest industrial economies (Canada, France, West Germany, Italy, Japan, the United Kingdom, and the United States), while Gordon focuses on comparing the United States with the United Kingdom and Japan.

${ }^{5}$ Haley (1990) presents a modern review of the microeconomic theories that predict Keynesian-type wage rigidity.

${ }^{6}$ However, economists have long noted the existence of informal organization by workers in nonunion settings (Dunlop [1957]). One version is the union-threat effect, where the threat of unionization forces owners to provide nonunion workers with benefits similar to those they would receive if unionized (Dickens [1986]).

${ }^{7}$ Local cost-of-living differentials are sometimes maintained for labor markets with notably higher prices. This is simply an extension of the desire to maintain consistency of wages across the firm, which may not reflect the labor market conditions for specific occupations.

\footnotetext{
${ }^{8}$ For a summary of unionism's implications for wage rigidity, see Mitchell (1986).
} 
${ }^{9}$ As economists pursue a deeper understanding of the internal labor market, wage equity has started to receive attention. In particular, Lazear (1989) describes circumstances where some salary compression (normally considered problematic by economists) is efficient. This is due to the possibility of detrimental, uncooperative behavior on the part of employees who are concerned about relative earnings.

${ }^{10}$ Examples of compensation policy references that describe and recommend these practices include Hills (1987), Milkovich and Newman (1990), and Wallace and Fay (1988).

${ }^{11}$ See Hills (1987), chapter 5.

${ }^{12}$ Employees may prefer this nominal guarantee because they (irrationally) fail to factor in the effects of price changes. More plausibly, many of their major expenses (such as fixed-rate mortgages) may be constant in nominal terms, or their sense of well-being may derive largely from relative comparisons with others.

${ }^{13}$ See, for example, Kahneman, Knetch, and Thaler (1986), Levine (1993), Bewley and Brainard (1993), and the citations in Kahn (1994). 
Table 1: Average Quarterly Adjustments for the U.S. Economy

\begin{tabular}{|c|c|c|c|c|c|c|c|c|}
\hline & \multirow{2}{*}{$\begin{array}{c}1960 \mathrm{~s} \\
\text { Expansion }\end{array}$} & \multicolumn{2}{|c|}{1970 s } & \multicolumn{2}{|c|}{$1980 \mathrm{~s}$} & \multicolumn{2}{|c|}{$1990 \mathrm{~s}$} & \multirow{2}{*}{$\begin{array}{c}\text { Coefficient of } \\
\text { Variation }\end{array}$} \\
\hline & & Recession & Expansion & Recession & Expansion & Recession & Expansion & \\
\hline $\begin{array}{l}\text { Percentage Change In: } \\
\text { Average Hourly Earnings }\end{array}$ & 5.2 & 6.9 & 7.5 & 6.5 & 3.9 & 2.9 & 2.8 & 0.38 \\
\hline Compensation per Hour & 5.8 & 9.2 & 8.3 & 8.4 & 4.7 & 5.0 & 4.1 & 0.32 \\
\hline Consumer Price Index & 2.6 & 9.0 & 6.8 & 8.4 & 4.3 & 5.7 & 3.2 & 0.44 \\
\hline Real Gross Domestic Product & 4.4 & -1.3 & 4.4 & -2.0 & 3.8 & -2.0 & 2.9 & 2.13 \\
\hline Total Nonfarm Employment & 3.1 & -0.4 & 3.4 & -1.2 & 2.8 & -1.4 & 1.7 & 1.84 \\
\hline Annualized Quarterly Change & & & & & & & & \\
\hline Unemployment Rate & 4.7 & 5.6 & 6.4 & 8.4 & 6.9 & 6.0 & 6.4 & 0.18 \\
\hline
\end{tabular}

Note: 1990 s include all periods up to July 1995.

Sources: U.S. Department of Labor, Bureau of Labor Statistics; and U.S. Department of Commerce, Bureau of Economic Analysis. 


\section{Table 2: International Unemployment Trends}

\begin{tabular}{l|rrrr}
\hline & 1960 & 1970 & 1980 & 1990 \\
\hline Australia & 2.0 & 3.9 & 7.6 & 9.5 \\
France & 1.7 & 3.9 & 9.3 & 11.1 \\
Germany & 0.7 & 2.1 & 5.9 & 5.5 \\
Italy & 3.2 & 3.7 & 6.4 & 9.2 \\
Japan & 1.3 & 1.7 & 2.5 & 2.5 \\
Sweden & 1.7 & 2.1 & 2.5 & 6.5 \\
United Kingdom & 2.7 & 4.6 & 10.1 & 9.2 \\
United States & 4.8 & 6.2 & 7.3 & 6.3 \\
\hline
\end{tabular}

Source: U.S. Department of Labor, Bureau of Labor Statistics. 
Monthly Salary

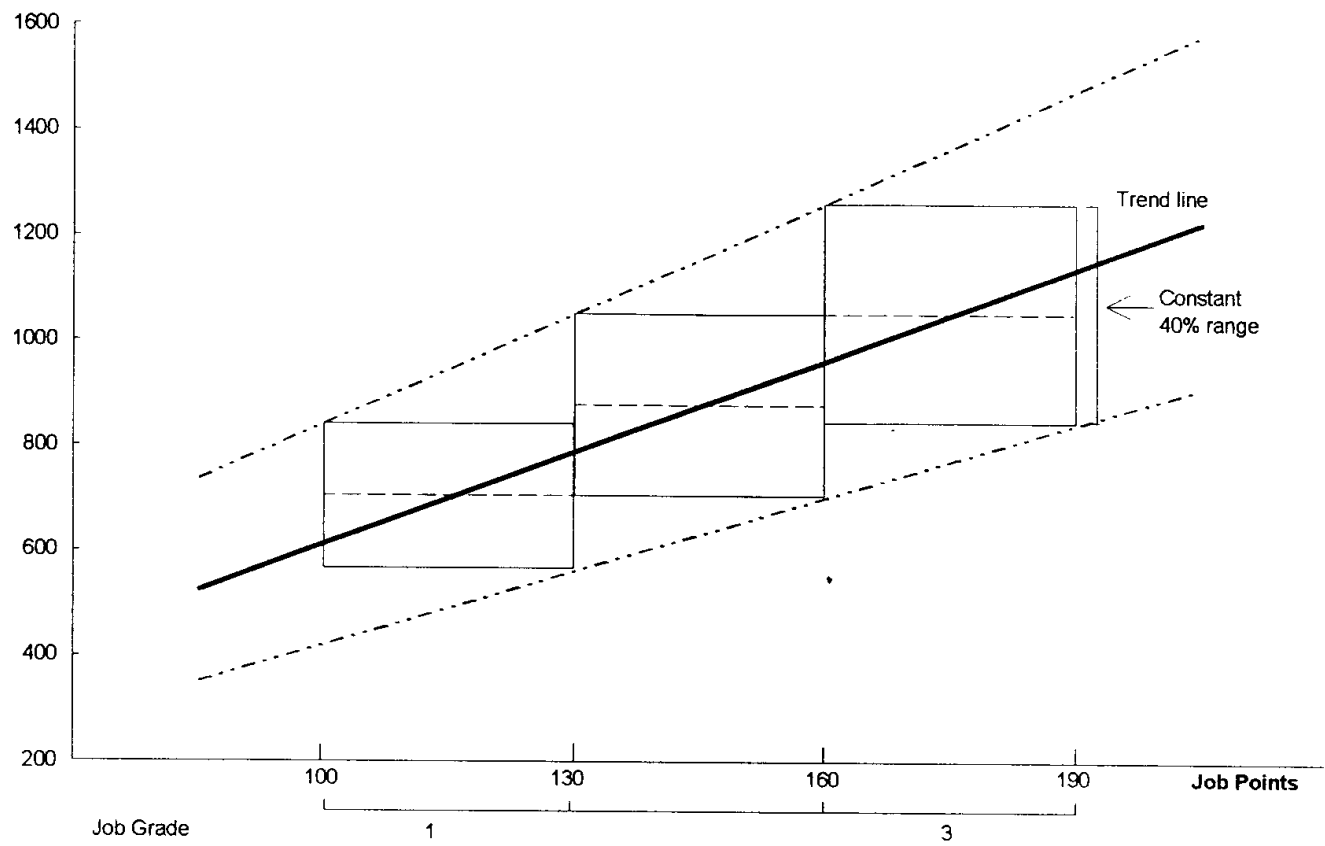

Source: Authors. 
Figure 2: Wage Adjustment with Downward Wage Rigidity

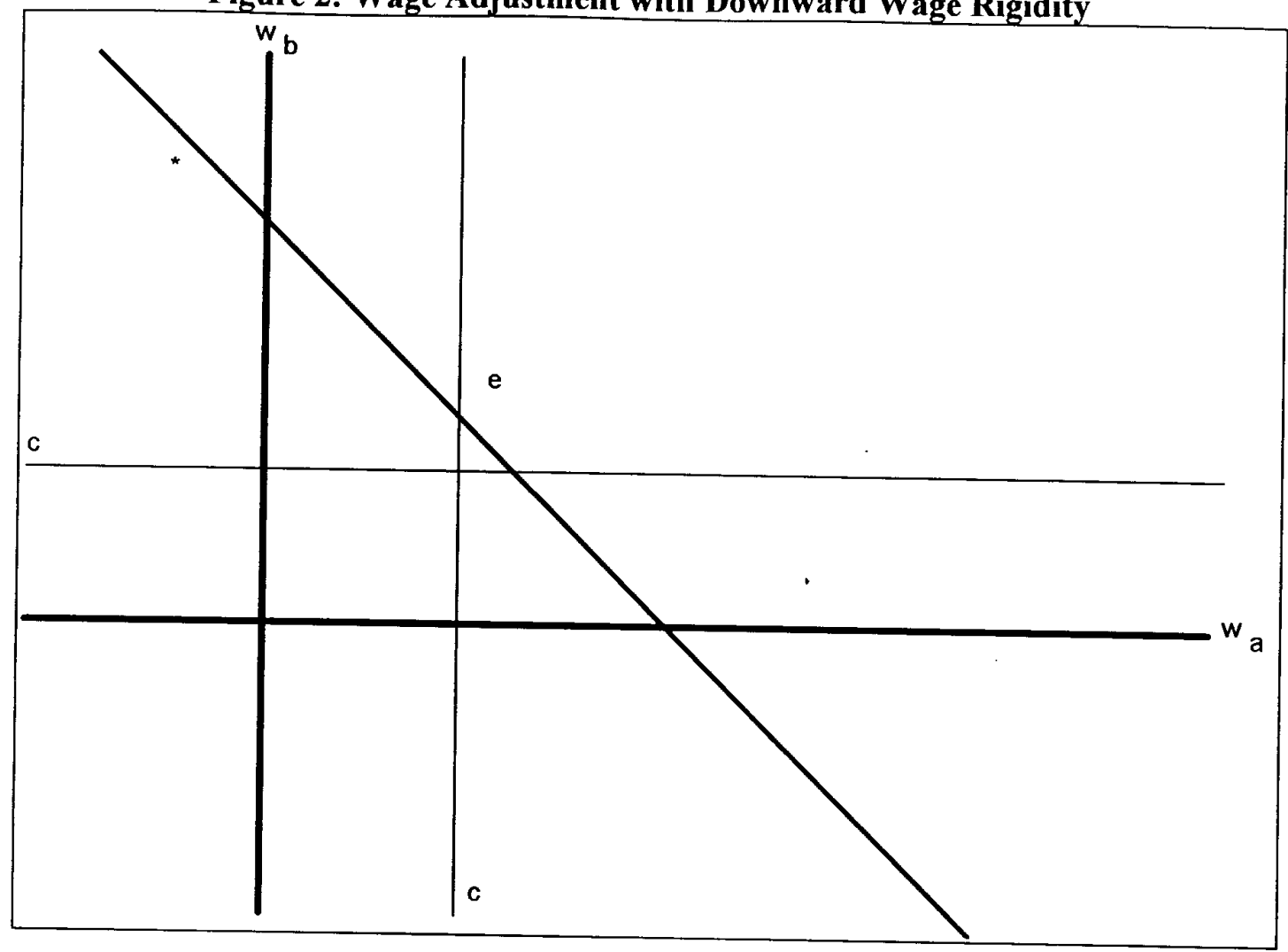

Source: Authors. 
Figure 3: Wage Adjustment with Wage Structure Rigidity

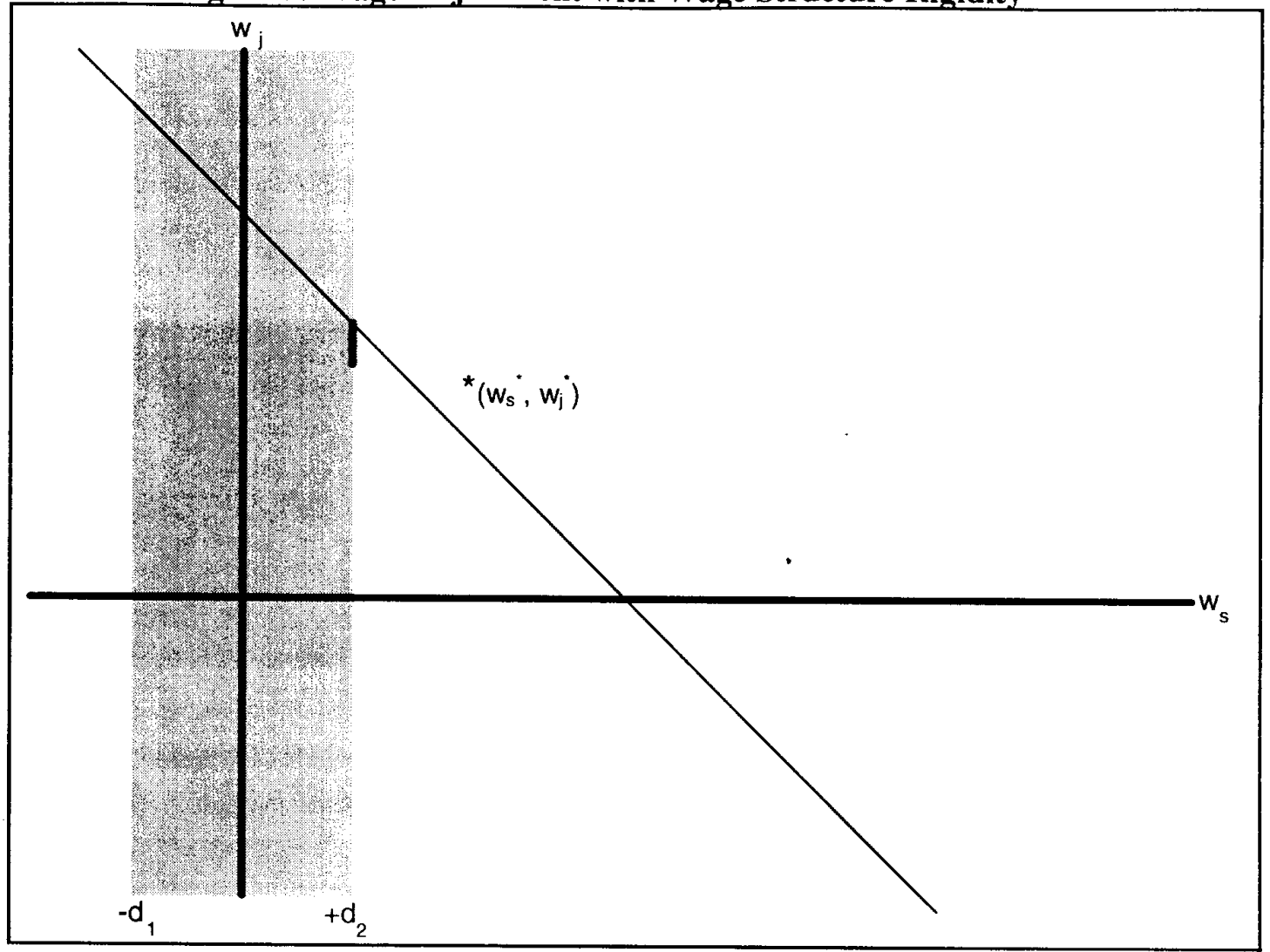

Source: Authors. 


\section{References}

Abraham, K. G., \& Haltiwanger, J. C. (1995). Real wages and the business cycle. Journal of Economic Literature, 33 (3), 1215-1264.

Adams, J. S. (1963a). Toward an understanding of inequity. Journal of Abnormal and Social Psychology, 67 (5), 422-436.

Adams, J. S. (1963b). Wage inequities, productivity, and work quality. Industrial Relations, 3, 9-16.

Akerlof, G. A. (1982). Labor contracts as partial gift exchange. Quarterly Journal of Economics 97 (4), 543-569.

Akerlof, G. A., \& Yellen, J. L. (1985). A near-rational model of the business cycle with wage and price inertia. Quarterly Journal of Economics, 100, (402), 823-838.

Akerlof, G. A., \& Yellen, J. L. (1986). Efficiency wage models of the labor market. Cambridge, U.K.: Cambridge University Press.

Allen, S. G. (1987). Relative wage variability in the United States, 18601983. Review of Economics and Statistics, 69 (4), 617-626.

Azariadis, C. (1983). Employment with asymmetric information. Quarterly Journal of Economics, 98 (392), 157-173.

Azariadis, C., \& Stiglitz, J. (1983). Implicit contracts and fixed price equilibria. Quarterly Journal of Economics, 98 (392), 1-22.

Baker, G., Gibbs, M., \& Holmstrom, B. (1994). The internal economics of the firm: Evidence from personnel data. Quarterly Journal of Economics, 109 (4), 881-920.

Baker, G., Gibbs, M., \& Holmstrom, B. (1994). The wage policy of a firm. Quarterly Journal of Economics, 109 (4), 921-955.

Ball, L., \& Mankiw, N. G. (1994, March). A sticky price manifesto. National Bureau of Economic Research Working Paper (No. 4677).

Ball, L., \& Romer, D. (1990). Real rigidities and the non-neutrality of money. Review of Economic Studies, 57 (2), 183-203. 
Barro, R. J. (1977). Long-term contracting, sticky prices, and monetary policy. Journal of Monetary Economics, 3 (3), 305-316.

Beckerman, W., \& Jenkinson, T. (1986). How rigid are wages anyway? In W. Beckerman (Ed.), Wage rigidity and unemployment (pp. 21-42). Baltimore: Johns Hopkins University Press.

Bell, L. A. (1986). Wage rigidity in West Germany: A comparison with the U.S. experience. Federal Reserve Bank of New York, Quarterly Review, 11 (3), 11-21.

Bergmann, T. J., \& Hills, F. S. (1987). A review of the causes of and solutions to pay compression. In L. R. Gomez-Mejia \& D. B. Balkin (Eds.), New perspectives in compensation (pp. 112-123). Englewood Cliffs, NJ: Prentice-Hall.

Bewley, T., \& Brainard, W. (1993, February). A depressed labor market, as explained by participants. Unpublished manuscript, Cowles Foundation, Yale University.

Bils, M. J. (1985). Real wages over the business cycle. Journal of Political Economy, 93 (4), 666-689.

Blanchflower, D. G., \& Oswald, A. J. (1987, March). Internal and external influences upon pay settlements: New survey evidence. Centre for Labour Economics Discussion Paper (No. 275). London: London School of Economics.

Blinder, A. S., \& Choi, D. H. (1990). A shred of evidence on theories of wage stickiness. Quarterly Journal of Economics, 105 (4), 1003-1015.

Bodkin, R. G. (1969). Real wages and cyclical variations in employment: A re-examination of the evidence. Canadian Journal of Economics, 2 (3), 353-374.

Bulow, J., \& Summers, L. (1986). A theory of dual labor markets with application to industrial policy, discrimination, and Keynesian unemployment. Journal of Labor Economics, 4 (3), 376-414.

Card, D. (1990). Unexpected inflation, real wages, and employment determination in union contracts. American Economic Review, 80 (4), 669-688.

Cogley, T. (1993). Empirical evidence on nominal wage and price flexibility. Quarterly Journal of Economics, 108 (2) 475-491.

Cukierman, A. (1983). Relative price variability and inflation: A survey and further results. Carnegie-Rochester Conference Series on Public Policy, 19, 103157. 
DeLong, J. B., \& Summers, L. (1984, September). The changing cyclical variability of economic activity in the United States. National Bureau of Economic Research Working Paper (No. 1450).

Dickens, W. (1986, March). Wages, employment and the threat of collective action by workers. National Bureau of Economic Research Working Paper (No. 1856).

Doeringer, P. B., \& Piore, M. J. (1971). Internal labor markets and manpower analysis. Lexington, MA: D.C. Heath and Co.

Dornstein, M. (1991). Conceptions of fair pay: Theoretical perspectives and empirical research. New York: Praeger.

Drazen, A., \& Hamermesh, D. S. (1986, January). Inflation and wage dispersion. National Bureau of Economic Research Working Paper (No. 1811).

Dunlop, J. T. (1957). The task of contemporary wage theory. In G. Taylor and F. Pierson (Eds.), New concepts in wage determination (pp. 117-139). New York: McGraw-Hill.

Dunlop, J. T. (1938). The movement of real and money wage rates. Economic Journal, 48 (191), 413-434.

Eberts, R., \& Groshen, E. L. (1991). Overview. In R. Eberts \& E. L. Groshen (Eds.), Structural changes in U.S. labor markets (pp. 1-12). Armonk, NY: M.E. Sharpe.

Fischer, S. (1977a). Long-term contracts, rational expectations, and the optimal money supply rule. Journal of Political Economy, 85 (1), 191-206.

Fischer, S. (1977b). Wage indexation and macroeconomic stability. Carnegie-Rochester Conference Series, 5, 107-147.

Fischer, S. (1981). Relative shocks, relative price variability, and inflation. Brookings Papers on Economic Activity, 12 (2), 381-442.

Freedman, A. (1976). The new look in wage policy and employee relations. The Conference Board Report (No. 865).

Garman, D. M., \& Richards, D. J. (1992). Wage-price flexibility, market power, and the cyclical behavior of real wages, 1959-1980. Quarterly Journal of Economics, 107 (4), 1437-1449. 
Geary, P. T., \& Kennan, J. (1982). The employment-real wage relationship: an international study. Journal of Political Economy, 90 (4), 854-871.

Gomez-Mejia, L. R., \& Balkin, D. B. (1987). Pay compression in an academic environment: The case of business schools. In L. R. Gomez-Mejia and D. B. Balkin (Eds.), New perspectives in compensation (pp. 124-134). Englewood Cliffs, NJ: Prentice-Hall.

Gordon, R. J. (1982). Why U.S. wages and employment behavior differ from that in Britain and Japan. Economic Journal, 92 (365), 13-44.

Gray, J. A. (1976). Wage indexation: A macroeconomic approach. Journal of Monetary Economics, 2 (2), 221-235.

Gray, J. A. (1988). Wage rigidity and unemployment: A review essay. Journal of Monetary Economics, 22 (2), 335-342.

Gray, J. A., Kandil, M., \& Spencer, D. E. (1992). Does contractual wage rigidity play a role in determining real activity? Southern Economic Journal, 58 (4), 1042-1057.

Gray, J. A., Kandil, M., \& Spencer, D. E. (1990). Some evidence on the role of contractual wage rigidity in determining real activity. Unpublished working paper, Brigham Young University.

Groshen, E. L. (1991). Five reasons why wages vary among employers. Industrial Relations, 30 (3), 350-381.

Groshen, E. L., \& Schweitzer, M. (1996, January). The effects of inflation on wage changes in firm-level data: Grease or sand? Federal Reserve Bank of New York, Staff Reports (No. 9).

Hahn, F. H., \& Solow, R. M. (1986). Is wage flexibility a good thing? In W. Beckerman (Ed.), Wage rigidity and unemployment (pp. 1-20). Baltimore: Johns Hopkins University Press.

Haley, J. (1990). Theoretical foundations for sticky wages. Journal of Economic Surveys, 4 (2), 115-155.

Hall, R. E. (1980). Employment fluctuations and wage rigidity. Brookings Papers on Economic Activity, 1, 91-123.

Hamermesh, D. S. (1986). Inflation and labour-market adjustment. Economica, 53 (209), 63-73. 
Hartman, R. (1991). Relative price variability and inflation. Journal of Money, Credit, and Banking, 23 (2), 185-205.

Hills, F. S. (1987). Compensation decision making. Hinsdale, IL: Dryden Press.

Hoehn, J. G. (1988). Procyclical real wages under nominal-wage contracts with productivity variations. Federal Reserve Bank of Cleveland, Economic Review, 24 (4), 11-23.

Holmstrom, B. (1983). Equilibrium long-term labor contracts. Quarterly Journal of Economics, 98 (392), 23-54.

Holzer, H. J., \& Montgomery E. B. (1990, March). Asymmetries and rigidities in wage adjustments by firms. National Bureau of Economic Research Working Paper (No. 3274).

Jackman, R. (1987). Wage flexibility. In J. Eatwell, M. Milgate \& P. Newman (Eds.), The new Palgrave: A dictionary of economics (vol. 4, pp. 833835). London: MacMillan Press.

Jacoby, S. M. (1985). Employing bureaucracy: managers, unions, and the transformation of work in American industry. New York: Columbia University Press.

Jacoby, S. M. \& Mitchell, D. J. B. (1980). Sticky stories: Economic explanations of employment and wage rigidity. American Economic Review, 80 (2), 33-37.

Kahn, S. (1994). Evidence of nominal wage stickiness from microdata. Unpublished manuscript, Boston University School of Management.

Kahneman, D., Knetch, J. L., \& Thaler, R. (1986). Fairness as a constraint on profit seeking: Entitlement in the market. American Economic Review, 76 (4), 728-741.

Katz, L. (1986). Efficiency wage theories: A partial evaluation. In S. Fischer (Ed.), NBER Macroeconomics Annual (pp. 235-276). Cambridge, MA: M.I.T. Press.

Kaufman, R. T. (1984). On wage stickiness in Britain's competitive sector. British Journal of Industrial Relations, 22, 101-112.

Keynes, J. M. (1939). Relative movements of real wages and output. Economic Journal, 49 (193), 34-51. 
Lang, Kevin. (1987, December). Persistent wage dispersion and involuntary unemployment. Unpublished paper, University of Michigan.

Lazear, E. P. (1989). Pay equality and industrial politics. Journal of Political Economy, 97 (3), 561-580.

Lebow, D. E., Stockton, D. J., \& Wascher W. L. (1994). Inflation, nominal wage rigidity, and the efficiency of markets. Board of Governors of the Federal Reserve System, Finance and Economics Discussion Series (No. 95-45).

Levine, D. I. (1993). Fairness, markets, and ability to pay: Evidence from compensation executives. American Economic Review, 83 (5), 1241-1259.

Levine, D. I. (1994). The U.S. labor market: 'Institutions' $\neq$ rigid and 'unregulated' $\neq$ market-clearing. In P. Voos (Ed.), Proceedings of the Forty-Sixth Annual Meeting of the Industrial Relations Research Association (pp. 177-185). Madison, WI: IRRA.

Lindbeck, A., \& Snower, D. J. (1986). Wage rigidity, union activity, and unemployment. In W. Beckerman (Ed.), Wage rigidity and unemployment (pp. 97125). Baltimore: Johns Hopkins University Press.

Lindbeck, A., \& Snower, D. J. (1987). Efficiency wages versus insiders and outsiders. European Economic Review, 31 (1/2), 407-416.

Lowenstein, G., \& Sicherman, N. (1991). Do workers prefer increasing wage profiles? Journal of Labor Economics, 9 (1), 67-84.

Lucas, R. E., Jr., \& Rapping, L. A. (1969). Real wages, employment, and the price level. Journal of Political Economy, 77 (5),721-754.

Mankiw, N. G. (1985). Small menu costs and large business cycles: A macroeconomic model of monopoly. Quarterly Journal of Economics, 100 (2), $529-537$.

McLaughlin, K. J. (1991, April). Rigid wages. Manuscript submitted for publication, University of Rochester.

Medoff, J. L. (1979). Layoffs and alternatives under trade unions in U.S. manufacturing. American Economic Review, 69 (3), 380-395.

Milkovich, G. T., \& Newman, J. M. (1990). Compensation. Homewood, IL: BPI-Irwin. 
Mitchell, D. J. B. (1985). Wage flexibility: Then and now. Industrial Relations, 24 (2), 266-279.

Mitchell, D. J. B. (1985). Wage flexibility in the United States: Lessons from the past. American Economic Review, 75 (2) 36-40.

Mitchell, D. J. B. (1986). Explanations of wage inflexibility: Wages and institutions. In W. Beckerman (Ed.), Wage rigidity and unemployment (pp. 4376). Baltimore: Johns Hopkins University Press.

Mitchell, D. J. B. (1993). Keynesian, old Keynesian, and new Keynesian wage nominalism. Industrial Relations, 32 (1), 1-29.

Montgomery, J. (1987, December). Equilibrium wage dispersion and interindustry wage differentials. Unpublished paper, Massachusetts Institute of Technology.

Nash, A. N., \& Carroll, S. J., Jr. (1975). The management of compensation. Belmont, CA: Wadsworth.

Nefci, S. N. (1978, part 1). A time-series analysis of the real wages-employment relationship. Journal of Political Economy, 86 (2), 281-291.

Prichard, R. (1969). Equity theory: A review and critique. Organizational Behavior and Human Performance, 4 (2), 176-211.

Rees, A., \& Schultz, G. P. (1970). Workers and wages in an urban labor market. Chicago: University of Chicago Press.

Reynolds, L. G. (1951). The structure of labor markets. New York: Harper \& Brothers.

Sachs, J. D. (1979). Wages, profits, and macroeconomic adjustment: A comparative study. Brookings Papers on Economic Activity, 2, 269-319.

Salop, S. C. (1979). A model of the natural rate of unemployment. American Economic Review 69 (1), 117-125.

Sargent, T. J. (1978). Estimation of dynamic labor demand schedules under rational expectations. Journal of Political Economy, 86 (6), 1009-1044.

Shapiro, C., \& Stiglitz, J. E. (1984). Equilibrium unemployment as a worker discipline device. American Economic Review, 74 (2), 433-444. 
Sheshinski, E., \& Weiss, Y. (1977). Inflation and costs of price adjustment. Review of Economic Studies, 44 (2), 287-303.

Slichter, S., \& Luedicke, H. (1957). Creeping inflation--cause or cure? Journal of Commerce, 1-32.

Solon, G., Whatley, W., \& Huff Stevens, A. (1994). Real wage cyclicality between the wars: Evidence from the Ford and Byers companies. Unpublished paper, University of Michigan.

Solow, R. (1985). Insiders and outsiders in wage determination. Scandinavian Journal of Economics 87 (2), 411-428.

Stigler, G. J., \& Kindahl, J. K. (1970). The behavior of industrial prices. National Bureau of Economic Research General Series (No. 90). New York: Columbia University Press.

Sumner, S., \& Silver, S. (1989). Real wages, employment, and the Phillips curve. Journal of Political Economy, 97 (3), 706-719.

Tobin, James. (1972). Inflation and unemployment. American Economic Review, 62 (1), 1-18.

Vining, D. R., \& Elwertowski, T.C. (1976). The relationship between relative prices and the general price level. American Economic Review, 66 (4), 699-708.

Wallace, M. J., Jr., \& Fay, C. H. (1988). Compensation theory and practice. Boston: PWS-Kent. 